\title{
THE FINAL PHASE OF THE INSULAR TARIFF CONTROVERSY.
}

It has been decided that after the ratification of the treaty with Spain our new possessions were domestic territory, and therefore import duties under our own tariff against foreign countries should not be levied on articles arriving here from Porto Rico and the Philippines. ${ }^{1}$ It was also decided as a correlative to the De Lima case that while, prior to ratification, duties levied by the military government in Porto Rico were valid, after that date those duties fell because the United States and Porto Rico were no longer foreign to each other." Notwithstanding these determinations, it was held that Congress might, by specific enactment, constitutionally lay import duties upon merchandise brought into this country from such territory, although domestic."

The ultimate stage in this aspect of our insular relations has now been reached by the presentation of cases to the Supreme Court which raise the issue of the validity of the tariff imposed in the Philippine Islands by our military and civil authorities upon imports from the United States (as well as the rest of the world) during the period between the ratification of the treaty and the specific approval and re-enactment of that tariff by Congress. On the one hand the claimants, trading houses engaged in business between this country and the East, have contended that the duties collected were invalid; that the territory being domestic, commerce with the United States must be free; that although there was an insurrection in the Philippines requiring the use of force to suppress, the war power under the Constitution was not involved and there was no such military necessity as to justify the imposition of a tariff against the products of this country; and, finally, that the point is completely ruled by the decisions in De Lima v. Bidwell, Dooley $v$. United States and the Fourteen Diamond Rings Case. The Government position is that this case is plainly to be distinguished from

I. DeLima v. Biduell, I82 U. S. I; Pepke v. United States (Fourteen Diamond Rings (ase), I83 U. S. I76.

2. Dooley v. United States, 183 U. S. 15I; the Foraker Act, 31 Statutes at Large of the U.S. 77 .

3 Downes ข. Bidwell, 182 U. S. 244. 
the previous adjudications; that a flagrant state of war prevailed during the whole period in question, the war power was involved and military necessities existed; and that this situation does not present a correlative to the Diamond Rings Case as the Dooley case was the correlative of the De Lima case; that, since Congress approved the executive action, Downes v. Bidwell controls.

The general question is of national concern and reaches far beyond the mere legality of the tariff exactions which occasioned the inquiry. The full competence and independence of the war power are involved. It is true that in the Diamond Rings Case the Government urged the prevalent state of war as a reason why the territory should be considered foreign with respect to our own tariff law, although sovereignty, title and possession had passed from Spain by the treaty. Peace was not attained, possession was sharply challenged and therefore, it' was argued in that case, the territory was not only hostile in fact but was foreign in point of law so far as our tariff was concerned and duties were properly imposed here on importations from the Philippines. But the court thought otherwise, and held that notwithstanding the insurrection, the legal title and possession of the United States remained unaffected and the territory was domestic. In the present case, however, the effect of the insurrection as a factor becomes real and acute. It concerns now, not the character of the country as domestic respecting our tariff under the Dingley law despite the state of war, but its condition as hostile, although domestic, respecting the local duties which the Executive deemed necessary to exact on imports from this country as well as the rest of the world. The question, therefore, is whether in that situation the war power was constitutionally. invoked and exercised and what was embraced within its scope.

The revolt in the Philippines was not a feeble insurrection; it was settled and serious rebellion. So far as duration and extent are concerned, it was civil war. The existence of the nation was not at stake as in the War of the Rebellion, and it was not civil war, perhaps, because a new people who had just come under our sovereignty turned against us their previous rebellion against Spain as soon as they realized we would not be complaisant." As our authorities appear to have viewed the matter, it was a situation not unfamiliar in various parts of the tropics-a determined attempt at revolution by a group of clever and selfish men seeking their own ends in the

\footnotetext{
- For distinctions see section Io, Lieber's Instructions for the Government of Armies in the Field; the Prize Cases, 2 B1., 635, 666.
} 
name of the people and under the guise of the sacred watch-words "liberty and independence." The war lasted three years. The insurrecto troops were well organized and disciplined. Tens of thousands of soldiers were serving on each side; thousands of them were killed or died of wounds; there were hundreds of engagements. The warfare lulled at one time after repeated open encounters, and our commanders then thought the end was near, but the conflict was renewed and maintained as a systematized guerilla warfare until it died out in sporadic instances of brigandage. Although there were encouraging statements in annual messages and reports of the Executive as to the progress of our arms and the gradual extension of our civil government, there can be no doubt that both the President and Congress realized and determined that a state of war prevailed and that the exercise of the war power was necessary.

The course of the Executive and legislative action was as follows: In July, 1898 , an executive order ${ }^{6}$ imposed duties, which through all the succeeding and minor modifications was substantially the preexisting Spanish tariff with the preferences to Spain stricken out. The treaty was ratified Àpril Ir, I899." The Executive continued the collection of the military tariff after the treaty was ratified, as before, first by the military authorities and then, in part, by the civil authorities after the commission assumed the legislative functions of government and shared in the civil administration." The "so-called "Spooner Amendment" was a resolution incorporated in an appropriation act and provided that "all military, civil and judicial powers necessary to govern in the Philippine Islands . .

The language of the order is: "By virtue of the authority vested in me as Commander in Chief . . . I do hereby order and direct that, upon the occupation and possession of any ports and places in the Philippine Islands by the forces of the United States, the following tariff of duties and taxes, to be levied and collected as a military contribution. . . . shall take effect and be in force."

30 Stat., p. I754.

'Instructions of the President to the Philippine Commission, April 7, 1900 (1 Pub. Laws Philippine Com., p. lxiii):

". . . the authority to exercise. . that part of the power of government in the Philippine Islands which is of a legislative nature is to be transferred from the military governor of the islands to this commission. . until the establishment of the civil central

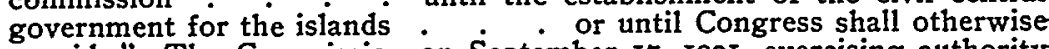
provide." The Commission on September I7, I9OI, exercising authority under the instructions and the Spooner Amendment, infra, reenacted the military tariff to take effect November I5, Igor (I Pub. Laws Philippine Com., p. 58r).

-Act of March 2, I90I (3I Stat., 895, 9ro). 
shall, until otherwise provided by Congress, be vested in such person and persons and shall be exercised in such manner as the President of the United States shall direct." In March, rgo2, Congress specifically enacted that the tariff act of the Philippine Commission "shall be and remain in full force and effect," and that there shall be levied upon all articles coming into the Philippines from the United States the same duties which are required on articles from foreign countries." In July, I902, the military government totally ceased and the civil government took its place. The President proclaimed the end of the war and amnesty, and Congress ratified the action of the President in creating and empowering the Commission, approved, ratified and confirmed the Philippine tariff order and its subsequent amendments, and recognized the insurrection as existing up to that date. ${ }^{10}$ On September 8, 1902, the Commission, in accordance with the requirement of the act of Congress of July $r$, relative to taking a census, formally certified that "a condition of general and complete peace has been established."

The power of an executive government in the field is very absolute. It may totally forbid all commercial intercourse or restrict it; It may exact military contributions to defray the expenses of war and to provide for the civil administration of the country on behalf of the peaceful inhabitants. The Executive may impose dues and charges as a condition for trading with hostile territory. Importation under such circumstances is not a right, but a privilege which may be exercised only upon the conditions imposed. These doctrines apply equally to foreign and civil wars, and the cases arising during our Civil War fully sustain them."

It was said in the Prize Cases that while the President has no power to initiate or declare a war either against a foreign nation or a domestic State, he is authorized to suppress insurrection and is bound to meet war in the shape presented without waiting for Congress to baptize it with a name; that it is anomalous to contend that a war levied by rebels in order to destroy a government is not a war because it is an insurrection; that in a domestic as well as a foreign war the belligerent party who claims to be sovereign may exercise

9. Act of March 8. 1602 (32 Stat. 54).

Io. Act of July $\mathrm{I}$, Ig02, Secs. $1,2,6 ; 32$ Stat. 69r.

rr. 2 Halleck Int. Law, 445-449; Matthews v. McStea, gr U. S. 7 ; I Kent's Com., 66; I Halleck Int. Law, 527; U. S. v. Grossmayer, 9 Wall. 72; Hanger v. Abbott, 6 Wall. 532; McKee v. U. S., 8 Wall. 163; The Prize Cases, 2 Bl. 635; Hamilton v. Dillin, 21 Wall. 73; The Reform, 3 Wall. 6ry; The Sea Lion, 5 Wall. 630; The Orsachita Cotton, 6 Wall. 52r; Coppell v. Hall, 7 Wall. 542; Mrs. Alexander's Cotton, 2 Wall. 404. 
both belligerent and sovereign rights. In Hamilton v. Dillin (note II) the determinations were to the same effect, and, in particular that the war power vested in the Government implied the right to suspend or license commercial intercourse without any specific mention of it in the Constitution. It was not necessary to decide in that case that in the absence of Congressional action the power of permitting intercourse with an enemy under restriction may be exercised by the President alone, but it was said that little doubt could be raised on the subject. The license to trade there took the form of what was called a bonus, rather than a tax, upon the shipment of cotton from insurrectionary districts to the loyal States. Congress passed a prior act which was held to authorize the executive action, and passed a subsequent act which approved and confirmed it. The view thus was, substantially, that in all three aspects the executive course was valid: as an exercise of the war power clearly within its sole competence, or under an authority in advance which Congress had the right to give, or under a subsequent ratification which was also within the power of Congress. The bonus or tax was a condition legitimately imposed by the Government upon traffic with hostile territory; no one was bound to accept it; no compulsion was exercised; the claimants had placed themselves in an entirely voluntary position and were not entitled to recover. Manifestly, unless such claims are determined to be valid, and the exercise of the war power, therefore, invalid and unconstitutional, there can be no notion of a vested right which a later enactment by Congress, undertaking to ratify the executive action, cannot defeat.

This case (Hamilton v. Dillin) and another Civil War case ${ }^{22}$ held that a particular place in the hostile country was none the less hostile because it was occupied by us in firm possession or was within our military lines. A condition of hostility remains impressed upon all the insurrectionary region until it is authoritatively removed at the close of the war. That condition is not removed as to particilar individuals and places merely because, and as fast and as far as, our armies succeed in occupying insurgent territory.

These doctrines of the Civil War cases were nevertheless earnestly challenged in the pending Philippine cases, and it was urged that since Manila was the headquarters of our military government and its civil agencies, and was, almost from the beginning of the insurrection, under our firm control, open to the commerce of the world, it could not, being domestic territory, be regarded as belligerent and

I2. Lamar v. Browne, 92 U. S. I87. 
hostile so as to justify the duties against the United States. These exactions were (it was claimed) clearly outside the military necessities of the case. It was argued on the authority of text books on international law that only domestic territory occupied by rebels, whose belligerency has beén recognized, can be regarded as foreign, and emphasis was laid upon the fact that our own courts had determined this territory to be domestic notwithstanding the prevailing insurrection. Now, it was said in illustration by the -Supreme court in the Dooley case (ante), that it could hardly be contended that a Northern commander occupying a Southern port during our Civil War could levy duties upon imports from the Northern States; that his power would not extend beyond the necessities of the case, and the claimants laid much stress upon this indication of the court's view.

If, however, despite the doctrines laid down as to the Civil War, the particular place is not to be considered hostile providing we have firm control there, then the logic necessarily means that the domestic port or place is not hostile or in enemy territory unless the enemy occupies and controls, which is a reductio ad absurdium, for in that case our commander could not impose conditions or levy duties at all. Nor does it seem likely that we must be challenged by street barricades in order to give the Executive full military jurisdiction. And the illustration from the Dooley case suggests on its face the very exception here, viz: a necessity when actual war prevails, which necessity can only be determined by the Executive as commander in the actual, critical situation. For, take the case of a Southern port occupied by our forces during the Civil War, as New Orleans was occupied and administered as a municipality under our military authorities from 1862 until the close of the war,-suppose, because of wide-spread and intense feeling for the rebellion, an active propagandism going on between native and foreign sympathizers within and the hostile forces without, all kinds of correspondence and aids, banking and trading agencies on behalf of the Confederacy,-it was deemed necessary by our commander to place an absolute embargo upon all commerce with New Orleans except from the surrounding country and under strict supervision through the military lines. It is quite certain that the power totally to forbid intercourse is lodged with the commander in war; that he must determine the necessity. and that the courts will not conjecture what were his motives and reasons and pass upon the degree of the necessity. If If this is a

13. Hamilton $v$. Dillin, ut sup., p. gr. Such considerations and conjectures are not material. 
legitimate and essential element of the law of war, it seems certain that a measure short of absolute restriction, a limited intercourse, would be valid, and therefore that a levy of duties upon all merchandise arriving by sea from the United States as well as foreign countries would be within the military power. That is to say, within the rule and illustration in the Dooley case the validity of the particular measure depends on the nature and necessities of the case, and the military commander must determine what a real crisis demands. Of course it is notorious that under the apparent peace at Manila, sedition, plotting and all kinds of correspondences with the insurgent forces were going on; the customs tariff and port administration were very effective means of supervision and control. The situation is typified by the fact that Aguinaldo's declarations of independence and war were posted beside the proclamations of our own commanders in the streets of Manila. Nor will it do to say that we could do all that was done except levy duties on merchandise from the United States. For purposes of revenue and strategy alike those duties may have been the most important. If they were not imposed, the Island government might have lost all ; for we are and were under treaty stipulation to admit Spanish ships and cargoes on the same terms as our own, and then other powers would certainly have invoked "the most favored nation clause."

It is essential, indeed, to remember the distinction between captured territory and hostile territory. Undoubtedly we could impose a blockade during war and would not pass a merchant vessel of our own, with a cargo of domestic production, through its lines. Blockade is a usual means of reduction bello flagrante; embargo is the exact equivalent when war is imminent or merely threatening, or during actual peace at home, when it is imposed for reasons of commercial necessity to meet aggressions upon neutral rights and protect those rights by retaliation. It seems natural to conclude that if a port is taken, we could maintain an embargo after capture during hostilities, just as much as under complete peace, and exclude domestic commerce then also if the executive authorities deemed that necessary. Certainly the Executive can proceed thus if Congress authorizes and approves. The inevitable inference is that if an emergency does not extend so far, but nevertheless exists, a fortiori we can do a less rigorous thing than establish blockade or embargo, viz.: impose duties and embrace domestic as well as foreign shipments.

These were the two contentions as to the intermediate authority conferred and the final ratification by Congress (the "Spooner 
Amendment" and the act of July I, I902, ante), viz: that, on the one hand, the power exercised by the President was legislative, valid until ratification of the treaty, thereafter invalid; that Congress cannot delegate legislative power to the Executive, and cannot subsequently ratify what it cannot authorize in advance. The contrary view is that the case is within the maxim that every subsequent ratification has a retroactive effect and is equivalent to a prior mandate." The law is well settled, and the test is: does the legislative body which ratifies possess authority to do the act or to confer power to do it, in the first instance ${ }^{\text {?5 }}$ Here the question is, did Congress possess authority, after ratification of the treaty, to impose duties on goods entering the Philippine Islands from the United States? The answer must, of course, be in the affirmative. ${ }^{26}$ The logic is this: the President validly acted or legislated up to the ratification; then Congress might have approved this action or legislation, previously valid, as continuing in force; and, authorizing later and ratifying finally, this action of Congress relates back with the same force and effect under the rule as a previous authority. The President continued to do something under his own previous legislation (if it were legislation), and Congress merely said, "Go on and do this," and finally declared, "What you have done is right." There was no unconstitutional delegation of legislative power. Where Congress might have accomplished the result by its legislation, it can ratify by legislation what was done without legislation other than the originally valid executive order. The legislative approval turned the valid power of the Executive to legislate, up to the date of ratification, into the equally valid power to continue to execute thereafter. The stress of the Civil War brought a plain determination of the point, without so much dialectics, as follows:

Whatever view may be taken as to the precise boundary between the legislative and executive powers in reference to the question under consideration, there is no doubt that a concurrence of both affords ample foundation for any regulations on the subject.

14. Omnis ratihabitio retrotrahitur et mandato equiparatur.

15. Marsh v. Fulton Co., Io Wall. 676; Norton v. Shelby Co., 118 U. S. 45I; Sykes v. Mayor, 55 Miss. 137; Grenada Co. v. Brogden, II2 U. S. 26I; Brown v. Mayor, 63 N. Y. 239; State v. Torinus, 26 Minn. I; McMillen v, Boyles, 6 Ia. 304; Mattingly $v$. District of Columbia, 97 U. S. 687; Thompson v. Lee Co., 3 Wall. 327; Supervisors v. Schenck, 5 Wall. 772; Gelpcke v. City of Dubuque, I Wall. 175; Fleckner v. U. S. Bank, 8 Wh. 338; Cooley, Const. Lim., 37 r.

16. Downes v. Bidwell, I82 U. S. 244.

I7. Humilton v. Dillin, ut sup., p. 88. 
In short, argument for the public side may be stated syllogistically as follows:

I. The start is with the war power and an imperative necessity for its exercise. That authority cannot be trammeled and must itself determine reasons, degree of necessity and what particular measures or compulsions are required. The courts will not usurp that function.

2. The De Lima case simply determined that Porto Rico was domestic territory respecting our tariff. The war power was not involved.

3. The Dooley case decided that subsequent to ratification the military tariff was not valid, because we had title and possession and there was no military necessity. The war power was not involved, but the door was left open in case it were.

4. The Diamond Rings case held that the Philippines were domestic territory, notwithstanding the insurrection, in respect to the legal elements of title and possession; that on this test duties levied here were invalid. Our own tariff was involved; the war power was not involved.

5. In the present cases the military tariff of the Philippines and paramount war necessities are presented. The war power is involved, and this issue is not the correlative of the Diamond Rings case as the Dooley case is the correlative of the De Lima case.

6. Under Downes v. Bidwell Congress might have continued the Philippine tariff including duties on merchandise entering from the United States, on April II, I899, as it did in March, I902. It is always well for the executive and legislature to concur in such emergencies, although it may not be constitutionally necessary. If it were, in this case Congress did by the statutes of March, Igor, and March and July, I902, accomplish as of the earlier date what it might have accomplished on the earlier date. It acted nunc pro tunc and ratified with the effect of a previous authority or previous act of its own.

Speaking from the broad standpoint of public interest and national capacity, it might well appear to the mind of any patriotic citizen that if the Executive cannot legally do what was done, when we are at war and the necessities are so vital, and if the joinder and approval of Congress have no effect, then we are indeed impotent as a nation. The constitutional authorities who act, the President and Congress, are acting together and in harmony, yet before a rebellion may be effectively suppressed and anarchy certainly averted, all details of revenue and administration must be referred back to Congress ten 
thousand miles away, in session only a portion of the time; formal war must be declared and every step must be prescribed and authorized by a statute in advance. Our safety and ability to prevent calamity, to maintain our rights and perform our duties, national and international, were at stake. It is not arguing from inconvenience or hypothetical calamities to say that whether we choose or not, we may be in a similar situation again. Where there are two possible constructions, one producing absurd and pernicious results, that one is to be avoided if consistent with reason. It is difficult to believe that the Constitution was intended to leave the national power in war and great emergencies so helplessly cramped and bound, or that it will be construed, in the settled interpretation of the law, to have that result.

In the final survey, on untechnical tests, in plain sense and reason, the question is whether the Executive and Congress did what was right; whether the demand to recover duties, voluntarily paid as a condition of trading with hostile territory, presents a just claim. The solemn inquiry now before the Supreme court is this: they are to determine whether, when the nation is struggling with war, is surrounded with difficulties and perils, the courts will assume to say that the combined action of the Executive and legislative went beyond the necessities, although there was no tyrannical aggression, no violation of sacred guaranties. The question of the scope of the war power once involved the very existence of the Government, and may do so again.

Henry M. Hoyt. 